Speck Gyula

\title{
A Bundeswehr humán stratégiája 2016 után
}

\begin{abstract}
A Bundeswehr 2010-es évek elején megkezdett reformjának következtében személyi állománya drasztikusan lecsökkent. A 2014-2016 folyamán kialakitott új külés biztonságpolitikai álláspont, a „müncheni konszenzus” értelmében Németország azonban erőteljesebb nemzetközi, egyben katonai szerepvállalás mellett tett hitet, amelyhez szükséges a haderő fejlesztése, igy a személyzeti reform is. Az évek óta tartó alulfinanszírozottság, a bürokratikus akadályok és sorozatos botrányok ellenére a Bundeswehrnek 2016-tól sikerült növelnie létszámát, egyúttal számos kezdeményezést indított útjára annak érdekében, hogy vonzóbb munkaadóvá váljon. Kérdés, hogy mindez mennyire lesz elég az új német stratégiai ambíciók megvalósításához.
\end{abstract}

Kulcsszavak: Németország, Bundeswehr, védelempolitika, haderőreform, Humán Stratégia

\section{The Bundeswehr's Personnel Strategy after 2016}

As a result of the reform of the Bundeswehr, which began in early 2010, its personnel have been drastically reduced. However, according to the new foreign and security policy guidelines developed during 2014-2016, the 'Munich Consensus', Germany must take a stronger international and military role, which requires the development of the armed forces, including personnel reform. Despite years of underfunding, bureaucratic hurdles and a series of scandals, the Bundeswehr has managed to increase its personnel since 2016, while launching some initiatives to make it a more attractive employer. The question remains whether all this will be enough to achieve the new German strategic ambitions.

Keywords: Germany, Bundeswehr, defence policy, military reform, personnel strategy

\section{Bevezető}

Az európai kontinens meghatározó hatalmának, a Németországi Szövetségi Köztársaságnak a hadereje a 2010-es években elhúzódó reformfolyamaton esett át. A haderö-átalakítás a haditechnikai eszközpark csökkentését, illetve a sorkatonai szolgálat felfüggesztését, így a személyi állomány drasztikus csökkenését okozta. ${ }^{2}$ E létszámcsökkentés a legnagyobb mértékű volt az európai haderők között. A személyi állomány csökkenését azonban 2016-tól sikerült visszafordítani: 2020 júliusában hat év után újra 185 ezer fő fölé nőtt a létszám. ${ }^{3}$ Felmerül a kérdés, hogyan sikerült a személyi állomány létszámát növelni az évek

Speck Gyula a Nemzeti Közszolgálati Egyetem doktorandusza. E-mail: speck.gyula@uni-nke.hu

Etl Alex - Csiki Varga Tamás: A Bundeswehr finanszírozása és készenléte. [online], Stratégiai Védelmi Kutatóintézet Elemzések, (2019), 20. 5-6. Forrás: svkk.uni-nke.hu [2020. 11. 10.]

3 Augen geradeaus: Personalstärke im August 2020: Mühsamer Aufstieg, jetzt wieder knapp über 184.000. [online], 2020. 09. 28. Forrás: augengeradeaus.net [2011. 11. 10.] 
óta tartó alulfinanszírozottság, a strukturális hiányosságok, a bürokratikus akadályok és a Bundeswehrről elterjedt botrányok ${ }^{4}$ ellenére. $^{5}$

\section{Stratégiai kontextus}

A 2014-2016 folyamán kialakított új német kül- és biztonságpolitikai álláspont, a „müncheni konszenzus” Németország erőteljesebb nemzetközi szerepvállalását határozta meg stratégiai célként, ami a politikai vezető szerep felvállalása mellett magában foglalja a robusztusabb katonai képességek fejlesztését annak érdekében, hogy Németország hiteles vezető nemzetté válhasson az európai kontinensen. Ennek megfelelően a német védelempolitika központi kérdésévé vált, hogy a Bundeswehr mennyire képes megfelelni az ambiciózus politikai célkitűzéseknek. Ahogy a 2016-ban kiadott biztonságpolitikai Fehér könyv (Weißbuch 2016 zur Sicherheitspolitik und zur Zukunft der Bundeswehr) fogalmaz, „a Bundeswehrnek képesnek kell lennie a német biztonságpolitika stratégiai prioritásainak megvalósításához való hozzájárulásra”. ${ }^{6}$

Napjainkban a németországi sajtó, ${ }^{7}$ a szakértők ${ }^{8}$ és maguk a katonák ${ }^{9}$ egyaránt hangsúlyozzák, hogy az új politikai célok miatt a Bundeswehrrel szembeni elvárások igen magasak, így nagymértékü nyomás helyeződik a személyi állományra. A szemléltetés kedvéért érdemes leszögezni, hogy 2020. novemberi állás szerint a Bundeswehr 3109 katonája ${ }^{10}$ szolgál 13 külföldi misszióban, három kontinensen. ${ }^{11}$ A Bundeswehr a missziók mellett a kollektív védelmi intézkedésekben is tekintélyes részt vállal: 2017 óta keretnemzeti feladatot lát el Litvániában több mint 500 fővel a NATO Enhanced Forward Presence (EFP) műveletében, valamint 2019-ben szintén keretnemzeti feladatot látott el a NATO Nagyon Magas Készenlétű Összhaderőnemi Kötelékében (Very High Readiness Joint Task Force - VJTF). Ezenfelül 2016-2017-ben a Bundeswehr menekültek képzésében is részt vett, amely feladatkör tovább terhelte a személyzeti állományt. ${ }^{12}$

A személyi állományt tovább terheli az új koronavírus-járvány is: a Bundeswehr elsősorban logisztikai támogatást nyújt a helyi szerveknek, továbbá támogatja a Szövetségi Egészségügyi Minisztériumot (Bundesministerium für Gesundheit) a védőeszközök beszerzésében. A válságkezelésre 2020 áprilisában a Bundeswehr történetében először állított fel

\footnotetext{
Például legutóbb szélsőjobboldali megnyilvánulások miatt egy különleges műveleti század teljes feloszlatása. Lásd: Zweite Kompanie der KSK aufgelöst. [online], 2020. 07. 30. Forrás: Deutsche Welle [2020. 12. 14.]

5 A Bundeswehr reformfolyamatáról és az akadályokról bővebben lásd: Csiki Varga Tamás - Etl Alex: Németország stratégiai jövőképe és a Bundeswehr reformfolyamata. [online], Honvédségi Szemle, (2020), 1. 25. Forrás: real.mtak.hu [2020. 11. 10.]

6 Bundesministerium der Verteidigung: Weißbuch 2016 zur Sicherheitspolitik und zur Zukunft der Bundeswehr. [online], 2016. 06. 88. Forrás: bmvg.de [2020. 12.12.]

Lásd pl.: ZDF: Armee am Limit - Was wird aus der Bundeswehr?. [online], Forrás: zdf.de [2020. 11. 11.]

$8 \quad$ Lásd pl.: Franz-Josef Meiers: Bundeswehr am Wendepunkt. Perspektiven deutscher Außen- und Sicherheitspolitik. Springer VS, 2017. 4.

9 Lásd pl.: Focus Online: Überlastung der Truppe: Bundeswehr droht der Kollaps - Verbandschef warnt. [online], 2020. 07. 10. Forrás: focus.de [2020. 11. 11.]

10 Bundeswehr: Personalzahlen der Bundeswehr. [online], Forrás: bundeswehr.de [2011. 11. 11.]

11 Bundeswehr: Aktuelle Einsätze der Bundeswehr. [online], Forrás: bundeswehr.de [2011. 11. 11.]

12 Deutsche Bundestag: Unterrichtung durch den Wehrbeauftragten. Jahresbericht 2019 (61. Bericht). [online], 2020. 01. 28. 69. Forrás: dip21.bundestag.de [2020. 11. 11.]
} 
egy belföldön bevetendő 15 ezer fős kontingenst (Hilfeleistung Corona) négy regionális vezetési törzs irányítása alatt. Bár a haderő gyorsan tudta a támogató feladatokat ellátni, a vírushelyzet mégis rámutatott a személyzeti problémákra. A 15 ezer fős válságkezelő kontingenssel és az Egészségügyi Szolgálat 17 ezer föjével együtt összesen 32 ezer katona áll készenlétben a koronavírus okozta válsághelyzet kezelésére. A külföldi missziókkal együtt tehát több mint 35 ezer katona vesz részt bevetésben, ami hosszú távon nehezen lesz fenntartható. A terhelés különösen a katona-egészségügyi személyzetet érinti, amely a belföldi feladatok miatt nem tud egyidejűleg a külföldi missziókban is részt venni. ${ }^{13}$

A megnövekedett elvárások és feladatspektrum miatt a Szövetségi Védelmi Minisztérium (Bundesministerium der Verteidigung) számára hamar nyilvánvalóvá vált, hogy a 2011-ben meghatározott 185 ezer fös felső létszámhatár nem tartható tovább, különösen annak fényében, hogy a személyi állomány 2016-ban történelmi mélypontra, 166500 före csökkent. ${ }^{14} \mathrm{~A}$ sorkatonai rendszer elvesztésével továbbá súlyos hiány keletkezett a szakemberállományban különösen az egészségügy és az információtechnológia terén. ${ }^{15}$

\section{Az új Humán Stratégia}

A „müncheni konszenzus” eredményeként megszületett új biztonságpolitikai stratégiai dokumentum, a 2016-ban kiadott Fehér könyv (teljes címén Weißbuch 2016 zur Sicherheitspolitik und zur Zukunft der Bundeswehr) kiemelte, hogy a Bundeswehrnek alkalmazkodnia kell a jelenlegi és a jövőbeli biztonságpolitikai környezethez: a haderőnek személyzetileg egyaránt képesnek kell lennie az országvédelmi, a kollektív védelmi, valamint a nemzetközi válságkezelő műveletek gyors, robusztus és fenntartható végrehajtására. A Fehér könyvben foglaltaknak megfelelően szakítani kell az évek óta tartó létszámzsugorodással, és egy fenntartható személyzeti politikát kell bevezetni. Ennek megfelelően a Bundeswehr létszámát az aktuális biztonságpolitikai követelményeknek megfelelően, rugalmasan kell meghatározni, merev létszámhatárok nélkül. ${ }^{16} \mathrm{~A}$ Fehér könyvben foglalt célok megvalósítására a védelmi minisztérium 2016 decemberében kiadta a Bundeswehr Humán Stratégiáját (Personalstrategie der Bundeswehr). A Humán Stratégia egy központi irányadó dokumentum a védelmi minisztérium és alárendelt szervei számára, amely meghatározza a Bundeswehr személyzeti menedzsmentjének alapvető irányait és fókuszpontjait. ${ }^{17}$

A dokumentum a Fehér könyv alapján megfogalmazott külső és belső befolyásolási tényezőket figyelembe véve határozza meg az irányokat. A külső tényezők közül kiemelendők a kedvezőtlen demográfiai kilátások: becslések szerint Németországban 2030-ra közel 4,4 millió fővel fog csökkeni a 15-66 év közötti keresőképes korosztály, a 18 év feletti

13 Claudia Major - Dominic Vogel: Die neuartige Rolle der Bundeswehr im Corona-Krisenmanagement. [online], Stiftung Wissenschaft und Politik - SWP Aktuell, (2020), 51. 1-5. Forrás: [2020. 11. 11.]

14 Major-Vogel (2020) i. m. 20.

15 Johannes Varwick: Von Leistungsgrenzen und Trendwenden. Was soll und kann die Bundeswehr?. [online], Aus Politik und Zeitgeschichte, (2020), 16-17. Forrás: bpb.de [2020. 11. 11.]

16 Bundesministerium der Verteidung: Weißbuch 2016 zur Sicherheitspolitik und zur Zukunft der Bundeswehr (2016) i. m. 119-120.

17 Ursula von der Leyen: Personalstrategie der Bundeswehr. [online], Bundesministerium der Verteidung, 2016. 9. Forrás: bmvg.de [2020. 11. 12.] 
német állampolgárságúak száma pedig 144 ezer fővel. Ezenfelül a társadalmi változások eredményeként a társadalom egyre inkább sokszínü lesz, megváltozik az egyének értékrendje és a munkahellyel, a karrierúttal szembeni elvárásaik, egyben a fokozódó individualizáció hatással van a vezetési és a kommunikációs struktúrákra, illetve a szervezeti kultúrára. Az egyének minél magasabb képzettség iránti igénye megnehezíti a toborzást, ugyanakkor állandósulni látszik a végzettséget nem szerző iskolaelhagyók száma. A másik fontos tényező a technológiai fejlődés, a digitalizáció és az automatizáció, amelyek új követelményeket támasztanak a haderővel szemben. A belső befolyásoló faktorok közül a dokumentum kiemeli, hogy a Bundeswehrnek önkéntességen alapuló haderőként aktívan kell a személyzeti utánpótlást biztosítania. A személyzeti hiányosságok a Bundeswehr katonai és civil állományában egyaránt jelen vannak: míg az előbbi esetében hiány van szakértőkből, elsősorban a tiszthelyettesi, illetve a technikai, információtechnológiai és egészségügyi tiszthelyettesi életpályán, addig az utóbbi esetében a technikai kiszolgáló személyzetben. A civil alkalmazottak fele 2030-ig nyugdíjas korú lesz, ezért fokozottan szükség van a fiatalabb munkavállalók bevonzására. ${ }^{18}$

A Humán Stratégiában megfogalmazott legfőbb cél, hogy a Bundeswehr vonzó és versenyképes munkaadóként rendelkezzen a szükséges, megfelelően képzett személyzettel feladatainak a megfelelő időben és helyen történő ellátásához, valamint tudjon az elvárásoknak megfelelően új, a személyzeti struktúra szempontjából releváns képességeket kialakítani vagy a már meglévő képességeit a helyzethez igazítva alkalmazni. E cél elérése érdekében a stratégia öt fejlődési irányt és azokon belül részcélokat határoz meg, amelyeket különböző kezdeményezésekkel és programokkal kell elérni. Az öt fejlődési irány és részcéljaik a következők:

1. Szisztematikus és stratégiai személyzeti tervezés. A Bundeswehrnek stratégiai személyzeti tervezést kell bevezetnie, ezen tervezési folyamathoz a védelmi minisztériumnak fel kell állítania egy vezetôi testületet, amely elemzi és meghatározza az aktuális civil és katonai létszámszükségletet.

2. A célcsoportoknak megfeleló toborzás és a teljesitóképesség kiaknázása. A toborzásnak a katonai és civil hiányszakma-területekre kell koncentrálnia, így új célcsoportok felé is kell nyitni, mint a 30 év feletti korosztályra vagy azokra, akik formai okok miatt nem felelnek meg egyes katonaiéletpálya-feltételeknek. A toborzásnak nyitnia kell az Európai Unió állampolgárai felé is. Ezenfelül vonzóbbá kell tenni a tartalékosi szolgálatot, például a részmunkaidő bevezetésével vagy a 12 hónapos szolgálat rugalmassá tételével. Javasolt a munkaadó cégeket még inkább jutalmazni, ha szolgálatra engedik el a tartalékosokat.

3. Fejlödési lehetőségek, karrierperspektivák és teljesitőképesség. Mivel a munkaeröpiacon kevesebb a szükséges szakértelem, különösen a hiányszakmákban, ezért a Bundeswehrnek saját magának kell szakképzéseket és továbbképzéseket biztosítania. A jelenlegi vertikális alapon rendeződő életpályákat rugalmasabbá, egymást között átjárhatóvá kell tenni, a személyzeti fejlödést egyénibbé, transzparensebbé és tervezhetőbbé kell alakítani.

18 Leyen (2016) i. m. 11-13. 
4. Korszerü munkakörnyezet és motiváció. Növelni kell a család és szolgálat közötti egyensúlyt, valamint a munkahelyi autonómiát, továbbá modernizálni szükséges a Bundeswehr szálláshelyeit, főleg az IT-eszközök terén. Az irodai pozíciók esetében rugalmasabbá kell tenni az időbeosztást és munkavégzés helyszínét például „home office napok" bevezetésével. A szolgálati jogviszonyt rugalmasabbá kell tenni, illetve versenyképes juttatási rendszerre van szükség, így pótolva a szakemberhiányt.

5. Akadálytalan átjárhatóság az életpályák között. A katonai állományt korábban általában rövid szolgálati idő és magas regenerációs igény jellemezte. Mindezt úgy kell megváltoztatni, hogy az idősebb életkorú állomány szolgálatát fejlődési lehetőségekkel kell egyénileg kialakítani, a (például egészségügyi) követelményeket át kell alakítani, összességében hatékonyabban és hosszabb ideig kell használni a katonákban rejlö szakértői és tapasztalati potenciált. A Bundeswehr támogatja a katonai szolgálatból kivált állomány megfelelő visszailleszkedését a civil munkaerőpiacra, így vonzó munkaadóként tüntetheti fel magát. Különösen a több ideje szolgáló katonák számára kell kialakítani speciális programokat, amelyek a gazdaság többi ágazatával való együttmüködésen alapulnak és másfajta foglalkoztatási viszonyt biztosítanak a közszférában. ${ }^{19}$

\section{Programok és kezdeményezések}

A fent felsorolt stratégiai célok megvalósítására kiemelt kezdeményezéseket és intézkedéseket ír elő a stratégia. A fenti fejlesztési irányokat a 2014 óta futó programokon kívül további, 2017-ben kezdődő intézkedések valósítják meg, amelyek egységesen a Stratégia Program 2025 név alatt futnak.

A 2014 óta futó programok a következők: ${ }^{20}$

- Vonzerői agenda (Agenda Attraktivität, teljes nevén „Bundeswehr in Führung - Aktiv. Attraktiv. Anders") 2014 májusa óta. Célja javítani a Bundeswehr foglalkoztatottjainak helyzetét és a Bundeswehr mint munkaadó vonzerejét az alkalmazottak és a civil társadalom számára egyaránt. Közel 50 intézkedést foglal magában, mint például a juttatások emelése, az életpályák javítása, a heti 41 órás munkaidő, gyermekgondozás, hozzátartozók gondozása, rugalmas munkaidő vagy a munkavégzési és szálláshelyek modernizálása.

- A Bundeswehrben való szolgálat vonzerejének növeléséről szóló törvény (Gesetz zur Steigerung der Attraktivität des Dienstes in der Bundeswehr) 2015 májusától. A törvény célja, hogy a 2018-as koalíciós szerződés értelmében csökkentse a haderőre nehezedő nyomást és ennek érdekében megfelelő jogi keretrendszert hozzon létre.

19 Leyen (2016) i. m. 15-25.

20 Leyen (2016) i. m. 27-30.; Bundeswehr: Die Trendwende Personal ist Erfolgreich!. [online], 2019. 11. 29. Forrás: bundeswehr.de [2020. 12. 01.]; Bundeswehr: Arbeitgeber Bundeswehr im Visier. [online], Ausgabe 01, Frühjahr 2016. 3. Forrás: bundeswehrkarriere.de [2020. 12. 14.] 
- Bundeswehr munkáltatói márkaépítés (Arbeitgebermarke Bundeswehr) 2015 októbere óta: célja, hogy a toborzás támogatásával a Bundeswehrt kvalifikált munkaadóként tüntesse fel.

- A 2014 óta futó Fegyverzeti agenda (Agenda Rüstung) egy koncepció, amely a projektcsoportok továbbképzéseit, képesítését kívánja jövőorientáltan és szisztematikusan átalakítani. Magában foglalja a Bundeswehr Felszerelésért, Információtechnológiáért és Szolgáltatási Támogatásért felelös Szövetségi Hivatalának (Bundesamt für Ausrüstung, Informationstechnik und Nutzung der Bundeswehr) mint munkaadó szerepének megerősítését, különösen a Bundeswehr civil mérnöki szakmák számára.

- Esélyegyenlőség, Sokszínüség és Inkluzió Törzsegység (Einrichtung Stabselement Chancengerechtigkeit, Vielfalt und Inklusion): A 2015 óta müködő törzsegység koordinál minden olyan projektet a védelmi minisztériumon belül, amelyek biztosítják, hogy a Bundeswehr állományának tagjai méltányos eséllyel folytathassák az életpályákat, a vezetési kultúrát ennek megfelelően alakítják át a képzésekben.

- A kiber- és információstér szervezeti terület felépítése (Aufbau Organisationsbereich Cyber- und Informationsraum): A föiskolai képzések vonzerejének növelését szolgálja a Müncheni Bundeswehr Egyetemen működő kiberklaszter, amely az informatika és a kibervédelem terén fog tanfolyamokat létrehozni. Ezenfelül létrejön egy kibertartalék is, amely a Bundeswehr feladatait hivatott végrehajtani az összállami biztonsági intézkedések kapcsán.

- 2016 májusában Ursula von der Leyen védelmi miniszter meghirdette a Személyzeti Irányváltás (Trendwende Personal) programját, amelynek célja, hogy minél gyorsabban növelje az állományt. A Személyzeti Irányváltás a korábbi gyakorlatokkal ellentétben szakít a mereven meghatározott felső létszámhatárral, helyette a Szövetségi Védelmi Minisztérium Középtávú Személyzeti Tervezés néven egy strukturált tervezési eljárást vezet be, amely során a védelmi miniszterből, a parlamenti államtitkárokból és a Bundeswehr föszemlélőjéből álló testület a következő hét évben évenként dönt a személyi állományról a Bundeswehr aktuális feladatspektrumát és a biztonságpolitikai helyzetet figyelembe véve.

Összességében megállapíthatjuk, hogy az új Humán Stratégia összhangban áll a müncheni konszenzussal és a 2016-os Fehér könyvben foglalt stratégiai célokkal, egyben rendkívül széles körű és szerteágazó dokumentum, amely azonosítja a Bundeswehr személyzeti kihívásait, a cselekvési irányokhoz pedig eszközöket rendel a végrehajtás érdekében, így tehát valóban stratégiai gondolkodást és tervezést tükröz vissza.

\section{A személyzeti reform kihívásai és eredményei}

A Humán Stratégiában foglalt intézkedések - legalábbis részben - napjainkra már éreztetik hatásukat. A hivatásos (Berufssoldaten) és szerződéses (Zeitsoldaten) állomány csökkenése megállt, 2016-tól növekedésnek indult: a 2016. júniusi 166500 fös katonai létszám 2019-re 175350 före nőtt, így közel 9000 fös emelkedést elérve (lásd az 1. ábrán), majd 2020 au- 
gusztusára az önkéntes szolgálatot teljesítőkkel (Freiwillig Wehrdienstleistende)21 együtt 185198 fö lett. E létszám szeptemberre 184258 före, majd októberre 183528 före csökkent vissza az időközben kilépő önkéntes szolgálatot teljesítők és a szerződéses katonák miatt. A 2020. októberi adatok szerint a 183528 főből 53302 hivatásos, 122154 szerződéses és 8072 önkéntes szolgálatot teljesítő. Ezenfelül a Bundeswehr állományában 81189 civil alkalmazott van. ${ }^{22}$

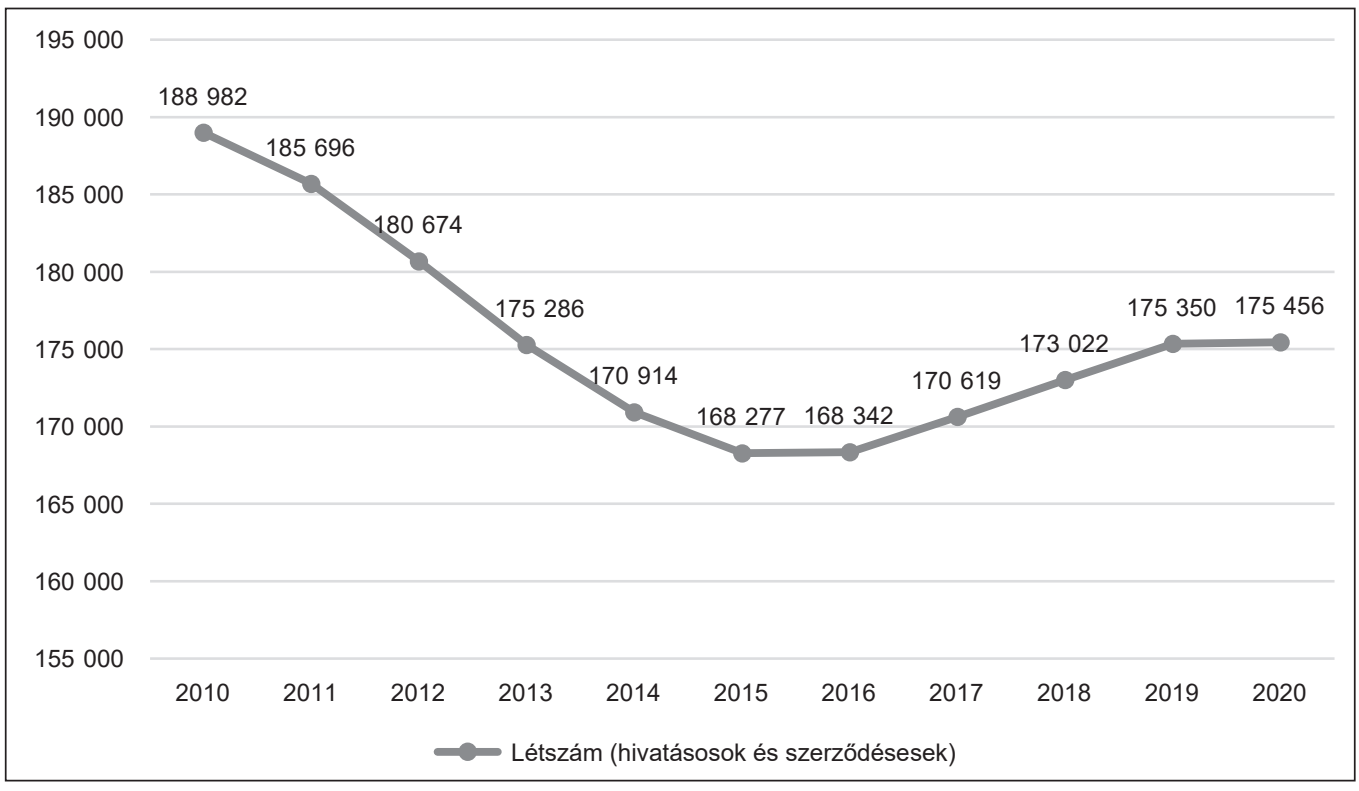

1. ábra: A Bundeswehr katonai létszámának alakulása (hivatásos és szerződéses állomány)

Forrás: Bundeswehr: Die Trendwende Personal ist Erfolgreich! (2019) i. m.; Bundeswehr: Personalzahlen der Bundeswehr i. m.

2020 májusában az évenkénti felülvizsgálat keretében Annegret Kramp-Karrenbauer védelmi miniszter jóváhagyta a Bundeswehr középtávú személyzeti tervét, amelynek értelmében 2027-ig a haderőnek 203 ezer katonai és 67800 civil alkalmazotti státusszal kell rendelkeznie. A korábbi, 2025-ig szóló tervhez képest az elérendő katonai státuszok száma nem változott, azonban az elérendő civil státuszok számát 1800-zal növelték. ${ }^{23}$

21 A sorkatonai szolgálat 2011-es felfüggesztésével a Bundeswehrben bevezették az önkéntes szolgálatot, amelynek keretében az állampolgárok 7-től 23 hónapig terjedő szolgálatot teljesíthetnek a csapatoknál, anélkül, hogy több évre el kellene köteleződniük. Az első hat hónapos próbaidő alatt mindkét fél felmondhatja a szerződést. Az önkéntes szolgálatra a 17. életévüket betöltött, oktatási kötelezettségüknek eleget tevő állampolgárok jelentkezhetnek. Sikeres kiképzés után külföldi missziókban is részt vehetnek. Lásd: Bundeswehr: Freiwilliger Wehrdienst (M/W/D): Chance statt Pflicht. [online], Forrás: bundeswehr.de [2020. 12. 02.]

22 Bundeswehr: Die Trendwende Personal ist Erfolgreich! (2019) i. m.; Bundeswehr: Personalzahlen der Bundeswehr. [online], 2020. 10. Forrás: [2020. 12. 02.]

23 Bundesministerium der Verteidigung: Personalbedarf bis 2027: Bundeswehr braucht mehr Zivilpersonal. [online], 2020. 05. 08. Forrás: bmvg.de [2020. 12. 01.] 


\section{Toborzás}

A személyi állomány növekedése a Bundeswehr tudósítása szerint a karriercentrumoknak, a munkaadói márkaépítési projekteknek és a Bundeswehrt népszerüsítő közösségimédia-reklámoknak, YouTube-filmeknek köszönhető. ${ }^{24}$ A Bundeswehr 16 karriercentrummal és 110 karrier-tanácsadó irodával rendelkezik, amelyek a Bundeswehr Szövetségi Humánmenedzsment-hivatala (Bundesamt für das Personalmanagement der Bundeswehr) alá tartoznak, feladatuk a Bundeswehr mint munkaadó képviselete, így a toborzás elősegítése, továbbá a katonák integrációja és a kilépők reintegrációja. ${ }^{25}$ A hivatal szervezete 2014 óta átszervezés alatt áll, azonban az átszervezést számos olyan kritika érte, miszerint a közel 2500 új státusz létrehozásával valójában tovább nőtt a Bundeswehr meglévő munkaerőhiánya. A hivatal az átszervezés kapcsán külső tanácsadó céggel konzultál a karriercentrumok átalakításáról. ${ }^{26}$

A toborzásban fontos szerepet kapnak a hirdetőkampányok, népszerüsítő események, karrierbörzék, különösen a fiatalok számára. A Bundeswehr többek között iskolások számára szervez sportversenyeket, beszélgetéseket, iskolákat látogat, előadásokat tart, illetve az iskolák is látogatásokat szerveznek a Bundeswehr laktanyáiban. 2019-ben a Bundeswehr soha ennyiszer nem szerepeltette magát állásbörzéken, mint 2019-ben (2620 alkalommal). A Bundeswehr erősödő kampánya ellen civil szervezetek demonstráltak és a Die Linke baloldali ellenzéki párt is felszólalt. ${ }^{27}$ A népszerüsítő kampányok sikeresen keltik fel a fiatalok érdeklődését a haderő iránt: egy 2020-ban készült felmérésben a német tanulók a második legszimpatikusabb munkaadónak értékelték a Bundeswehrt. ${ }^{28} \mathrm{~A}$ fiatalok érdeklődését az is mutatja, hogy a 17 éves korú jelentkezők száma enyhén növekszik: 2019-ben 1706-an jelentkeztek, míg 2018-ban még csupán 1679-en, így a szolgálatukat megkezdők kevesebb, mint 10\%-a 17 éves. ${ }^{29} \mathrm{~A}$ Bundeswehrt népszerüsítő média (például a „Die Rekruten” filmsorozat) bár felkelti az álláskeresők érdeklődését, azonban a karriercentrumokban kínált állásajánlatok gyakran nem találkoznak elképzeléseikkel. A Bundestag honvédelmi megbízottja (Wehrbeauftragter des Deutschen Bundestages), Dr. Hans-Peter Bartels 2019. évi jelentésében felhívja arra a figyelmet, hogy szerencsés lenne, ha az érdeklődők több olyan csapatlátogatáson tudnának részt venni, mint amilyet például jelenleg a haditengerészet kieli látogatóközpontja kínál. ${ }^{30}$

A hirdetőkampányok és a karriercentrumok mellett a Bundeswehr a „személyi elkötelezettség" (Personalbindung) kezdeményezéssel is igyekszik a munkaerőhiányt pótolni, amely a katonák szolgálati idejének meghosszabbítását teszi lehetővé önkéntes alapon. A honvédelmi megbízott szerint ennek ellenére továbbra is gyakori probléma, hogy a katonáknak nem ajánlják fel a hosszabbítás lehetőségét. Ezt orvosolandó a védelmi minisz-

\footnotetext{
24 Bundeswehr: Die Trendwende Personal ist Erfolgreich! (2019) i. m.

25 Bundeswehr: Was macht ein Karriercenter?. [online], Forrás: [2020. 12. 04.]

26 Deutsche Bundestag: Unterrichtung durch den Wehrbeauftragten. Jahresbericht 2019 (61. Bericht) (2020) i. m. 27.

27 Bernd Kramer: Wie oft Bundeswehr in Klassenzimmern wirbt. [online], 2020. 08. 21. Forrás: sueddeutsche.de [2020. 12. 10.]

28 Bundeswehr: Corona-Krise: Bundeswehr bleibt attraktiver Arbeitgeber und will weiter wachsen. [online], 2020. 06.15. Forrás: bundeswehr.de [2020. 12. 02.]

29 Deutsche Bundestag: Unterrichtung durch den Wehrbeauftragten. Jahresbericht 2019 (61. Bericht) (2020) i. m. 32.

30 Deutsche Bundestag: Unterrichtung durch den Wehrbeauftragten. Jahresbericht 2019 (61. Bericht) (2020) i. m. 28.
} 
térium tájékoztatásokat fog közölni a pozíciók betöltését megelőzően hat hónappal, így a posztot betöltő vagy az arra alkalmas katonák tájékozódhatnak a további szolgálati lehetőségekről. Ehhez hasonlóan 2017-ben úgynevezett orientációs napokat vezettek be a kiképző és támogató századoknál, amelyek során az újoncok már kiképzésük elején előadások, látogatások révén képet kaphatnak a beosztásokról. Ugyanígy a légierőnél (Luftwaffe), haditengerészetnél (Marine), az Összhaderőnemi Támogatószolgálatnál (Streitkräftebasis), illetve a Kiber- és Információs Tér szervezeti elemnél személyfejlődési csapatokat hoztak létre, amelyek az önkéntes szolgálatot teljesítők számára tanácsadást és egyéni beszélgetéseket szerveznek a karriercélokról és az életpálya-perspektívákról. A toborzás erősítésében elörelépést hozott továbbá a Bundeswehrben való szolgálat vonzerejének növeléséről szóló 2015-ös törvény, amely lehetővé teszi, hogy a szolgálati időt meghosszabbítók számára anyagi juttatásokat adjanak. A törvény értelmében a juttatás feltétele, hogy a katona a szolgálati idejének utolsó 36 hónapjában kérvényezze a hosszabbítást. 2015-2019 között 4690, elsősorban a szaktudást igénylő (főleg IT és repüléstechnikai) tiszthelyettesi és őrmesteri életpályát folytató katona kapott juttatást. A katonák nagy részben négyéves hosszabbítást vállaltak, egy átlagos jutalom összege 20500 euró (közel 7,4 millió forint) volt. Jutalmat azon hivatásosok is kaphatnak, akik olyan személyzeti hiánnyal küzdő területeken dolgoznak, ahol felmondási hullám fenyeget. ${ }^{31}$

A munkaerőhiány pótlásában fontos szerepet kapnak az újra belépők és katonai előélettel nem rendelkező belépők. 2018-ban 16 360, 2019-ben 16746 katonai elóélettel nem rendelkező egyén jelentkezett a Bundeswehrbe. A honvédelmi megbízott szerint e jelentkezések magas száma azt mutatja, hogy a haderő vonzó munkaadó, amely széles körben kínál munkaköröket a polgári végzettséggel rendelkezők számára, például a mérnöki, IT-, sport-, hírszerzési vagy egészségügyi területen. ${ }^{32}$

A Bundeswehr humán reformja kapcsán nagy médiafigyelmet kapott az uniós állampolgárok Bundeswehrbe való toborzása, amelyet a 2016-os Fehér könyv és a Humán Stratégia egyaránt megemlített mint jövőbeli lehetőséget a létszámhiány, különösen a szakemberhiány orvoslására. A Bundeswehr kétségkívül vonzó munkaadó lenne az európai katonák számára: a Bundeswehr tiszti átlagfizetése az európai tiszti fizetések élvonalába tartozik (összehasonlításképpen: egy német tiszti kezdő fizetés havi 3336, míg egy lengyelé 755 euró), a tiszthelyettesi és legénységi kezdő fizetés pedig a legmagasabb Európában, ugyanakkor az „agyelszívó” hatás miatt jelentős konkurenciát jelentene az alacsonyabban fizetett haderők számára. ${ }^{33}$

\section{Felsőoktatás, képzések}

A rendkívül széles képzési profil a Bundeswehr vonzerejének fontos eleme, ugyanis Németország egyik legnagyobb képzést és oktatást biztosító szervezete, közel 260 civil és 4000 katonai képzést kínálva. A Bundeswehr felsőoktatási tevékenysége különbözik a többi németországi felsőoktatási intézménytől. A Bundeswehr két egyetemmel

\footnotetext{
31 Deutsche Bundestag: Unterrichtung durch den Wehrbeauftragten. Jahresbericht 2019 (61. Bericht) (2020) i. m. 27-30.

32 Deutsche Bundestag: Unterrichtung durch den Wehrbeauftragten. Jahresbericht 2019 (61. Bericht) (2020) i. m. 31.

33 René Schulz: Streitkräfte europäischer denken. SWP Aktuell, (2019), 48. 3-4. Forrás: swp-berlin.org [2020. 12. 10.]
} 
rendelkezik (a hamburgi Helmut Schmidt Egyetem és a Müncheni Bundeswehr Egyetem), amelyeken egyaránt futnak civil és katonai alap- és mesterképzések, valamint müködnek kutatói hálózatok. Az egyetemi képzések igen népszerűek a fiatalok körében, a hallgatók száma évről évre növekszik. ${ }^{34}$

A két Bundeswehr-egyetemmel együtt a hamburgi székhelyü Bundeswehr Vezetői Akadémiája (Führungsakademie der Bundeswehr) képezi a katonai felsőoktatás gerincét. Az egyetemi hallgatói státuszok döntő része katonák számára van fenntartva, a civil ösztöndíjak száma alacsony. A tisztnövendékek 13 éves katonai életpályára kötelezik el magukat (pilótáknál 16 év, orvosoknál 17 év), amely egy 11-15 hónapos alapkiképzéssel kezdődik, ezt követően kezdik meg négyéves ( 3 év alapképzés, 1 év mesterképzés) felsőoktatási tanulmányaikat, mialatt mentesülnek a katonai feladatoktól, ezt követően egy értékelő központban (Assesment Center) állapítják meg a tiszti beosztásokra való alkalmasságukat. Az egyetemek olyan képzéseket is kínálnak, amelyek más egyetemeken is megtalálhatók (például orvosi, állatorvosi, jogi, bölcsészettudományi, gazdasági, mérnöki, társadalomtudományi), de egyben illeszkednek a Bundeswehr igényeihez is. A tisztképzés részét képező felsőoktatási végzettség megszerzése azt a célt szolgálja, hogy a tiszteket felkészítse a szolgálati idejüket követő civil életpályára is, összhangban a német haderő „egyenruhás polgárok” (Staatsbürger in Uniform) elvével. ${ }^{35}$ Komoly vonzerőt jelent, hogy a hallgatók már tanulmányaik alatt teljes illetményre jogosultak, függően a rendfokozattól, továbbá lakhelyet is kapnak az egyetem campusain. Az illetmény havi nettó 1600-2200 euró között mozog. $\mathrm{Az}$ alapképzés három évének elvégzése után a tisztnövendékeket hadnaggyá (Leutnant), majd a mesterképzés után főhadnaggyá (Oberleutnant) léptetik elő, így a juttatások is növekszenek..$^{36} \mathrm{~A}$ tanulmányok elvégzését követően a tisztek további szakképzéseken vesznek részt szolgálatuk folyamán.

A védelmi minisztérium szerint magas a Bundeswehr egyetemeken végzettek aránya: például a hamburgi egyetemen az alapképzést a hallgatók 72\%-a, a mesterképzést a hallgatók 92\%-a végzi el. ${ }^{37} \mathrm{~A}$ honvédelmi megbízott jelentése ugyanakkor rávilágít arra, hogy 2019-ben 1451-en kezdtek el alapképzést, közülük 302-en szakítottak tanulmányaikkal, nagy részük pont a Bundeswehr számára fontos gépészeti, elektrotechnikai, információtechnikai képzések hallgatója volt. A lemorzsolódást megakadályozandó a 2019-ben életbe lépő, Bundeswehr-készenlétet növelö törvény (teljes nevén: Gesetz zur nachhaltigen Stärkung der Personellen Einsatzbereitschaft der Bundeswehr) értelmében a tanulmányaikat abbahagyó hallgatók a Bundeswehrből való kilépésüket követően csak fél évig jogosultak a képzések által biztosított támogatásokra, így eltántorítva a hallgatókat a kilépéstől. ${ }^{38}$

A civilképzés profilja kiterjed az információtechnológiai, egészségügyi, igazgatási, logisztikai és ipari területekre a főiskolai vagy szakmunkásképzésektől az akadémiai szféráig.

\footnotetext{
4 Deutsche Bundestag: Unterrichtung durch den Wehrbeauftragten. Jahresbericht 2019 (61. Bericht) (2020) i. m. 22.

35 Bundeswehr: Arbeitgeber Bundeswehr im Visier. [online], Ausgabe 13, Frühjahr 2020. 3. Bundesministerium für Verteidigung Presse- und Informationsstab Forrás: bmvg.de [2020. 12. 10.]; Bundeswehrkarriere: Offizier mit Studium in der Laufbahn der Offiziere. [online], Forrás: bundeswehrkarriere.de [2020. 12. 10.]; Studium Ratgeber: Studium bei der Bundeswehr. [online], Forrás: studium-ratgeber.de [2020. 12. 10.]

36 Karista: Offizier Gehalt. [online], Forrás: karista.de [2020. 12. 10.]

37 Bundeswehr: Arbeitgeber Bundeswehr im Visier. (2020) i. m. 4.

38 Deutsche Bundestag: Unterrichtung durch den Wehrbeauftragten. Jahresbericht 2019 (61. Bericht) (2020) i. m. 23.
} 
A civilképzések fontos vonzó tényezőt jelentenek a szerződéses szolgálatot vállalók számára, lévén, hogy ezzel katonai szolgálatuk után is el tudnak helyezkedni a munkaerőpiacon. 2019-ben előrelépés volt, hogy a Bundeswehr egy kísérleti projektet kezdett az iskolai végzettséggel nem, de legalább 18 hónapos szolgálati idővel rendelkező legénységi állományúak részére, amelynek keretében a katonák hat hónapon belül általános iskolai végzettséget szerezhetnek, így megnyitva a lehetőséget az életpályaváltásra. A honvédelmi megbízott továbbá korábban javaslatot tett arra, hogy a civilszakmai képzések és továbbképzések a hosszabb ideje szolgáló legénységi állományúak számára is elérhetők legyenek. A haditengerészetnél szintén egy kísérleti projekt keretében lehetővé tették, hogy a legénységi állományúak szakvégzettséget szerezzenek az elektrotechnika vagy meghajtástechnika terén, amellyel később szakértőként szolgálhatnak tovább, így pótolva a sürgető szakemberhiányt. A védelmi minisztérium azonban egyelöre nem látja szükségét annak, hogy a civilképzési intézkedéseket kiterjesszék minden legénységi állományú részére. ${ }^{39}$

\section{Katonai életpályák}

A Bundeswehrben jelenleg legénységi, tiszthelyettesi és tiszti életpályák vannak. A legénységi életpályán kezdenek a tiszthelyettesi vagy tiszti életpálya várományosai, valamint az önkéntes szolgálati viszonyt teljesítők is. A legénységi életpályát folytatók a legalacsonyabb rendfokozattal, három hónapos alapkiképzéssel kezdenek, amelyet követően szolgálatba állnak. A legmagasabb legénységi rendfokozathoz (Oberstabgefreiter, vagyis szakaszvezető) legalább 4 év szolgálatot kell teljesíteniük. Míg az önkéntes szolgálatot teljesítők 7-23 hónapos szolgálat keretében ismerkednek meg a katonai szakmával, ezt követően szerződésesként szolgálhatnak tovább, addig a szerződéses katonák legalább kétéves szolgálatot teljesítenek. A megfelelő iskolázottsággal vagy szakképzéssel rendelkezők magasabb (például tiszthelyettesi) életpályákra léphetnek. ${ }^{40}$

A tiszthelyettesi életpályán belül megkülönböztetnek alacsonyabb (Unteroffizier ohne Portepee) és magasabb rendfokozatú tiszthelyetteseket (Unteroffizier mit Portepee, ide tartoznak a különböző őrmesteri rendfokozatok). A tiszthelyettesek szolgálati ideje általában 12 év. Míg a hadapród őrmesterek és a kadétok (Fahnenjunker, Seekadett) a tiszti életpályát folytatva még a képzési szakaszban állnak, addig a többi alacsonyabb tiszthelyettesi rendfokozatú (Unteroffizier, Stabsunteroffizier - magyarul altiszt, törzsaltiszt) később őrmesterként (Feldwebel) folytatja szolgálatát. A legtöbb alacsonyabb rendfokozatú tiszthelyettes valamilyen szakterületre specializálódik (például egészségügy, személyi tanácsadó), a magasabb rendfokozatú tiszthelyettesek pedig csapatszolgálat esetén csapatparancsnoki beosztást, szakképzettség megszerzése esetén pedig valamilyen szakbeosztást látnak el. A magasabb rendfokozatú szakértői tiszthelyettesek a tiszti életpályára válthatnak. ${ }^{41} \mathrm{~A}$ tiszti életpályát választóknak 13-17 éves szolgálati viszonyt kell teljesíteniük és egyéves tisztképzésen kell

39 Deutsche Bundestag: Unterrichtung durch den Wehrbeauftragten. Jahresbericht 2019 (61. Bericht) (2020) i. m. 38-39.

40 Bundeswehr: Laufbahn der Mannschaften - Das Rückgrat der Bundeswehr. [online], Forrás: Bundeswehr.de [2020. 12. 07.]

41 Bundeswehr: Die Unteroffiziere ohne Portepee (M/W/D). [online], Forrás: bundeswehr.de [2020. 12. 07.]; Bundeswehr: Die Laufbahn der Unteroffiziere mit Portepee (M/W/D). Forrás: bundeswehr.de [2020. 12. 07.] 
részt venniük. A tiszti várományosok nagy része a Bundeswehr hamburgi vagy müncheni egyetemén szerez végzettséget, amelyet további szakértői kiképzés követ. ${ }^{42}$

A 2016-os Humán Stratégia alapján a Bundeswehr közel 15 intézkedést hozott a katonai életpályák megreformálása érdekében. Ilyen például a szaktiszti életpályáról a csapattiszti életpályára való váltás átalakítása, vagy hogy a kiemelkedő teljesítményt nyújtó katonák az őrmesteri életpályára léphetnek, amennyiben hivatásos szolgálati viszonyra váltanak. Ezenfelül a népszerüsítés érdekében a legénységi életpályát kibővítették további kettő rendfokozattal (káplár és törzskáplár, németül Korporal, Stabskorporal). Az első előléptetésekre 2021-ben fog sor kerülni. ${ }^{43}$ Korábban a legénységi életpályán a legmagasabb fizetési kategóriában közel bruttó 2367 euró volt a havi fizetés további 43,37 eurós pótlékkal. Ezzel szemben a káplár rendfokozattal bruttó havi 2417 euró, a törzskáplár rendfokozattal ehhez további bruttó 51 eurós pótlék jár. ${ }^{44} \mathrm{~A}$ honvédelmi megbízott szerint azonban az új rendfokozatok bevezetése olyan problémákba ütközhet, mint hogy nehéz lesz megkülönböztetni a szakaszvezetői és a káplári felelősségi köröket, vagy hogy az új rendfokozatokkal szélesebb körü tiszthelyettesi feladatköröket kell ellátni, valamint hogy mindez további adminisztratív terheket ró a haderőre. ${ }^{45}$ További intézkedés, hogy a Bundeswehr vonzerejét erősítő 2015-ös törvény értelmében a szaktiszthelyettesek hivatásos szolgálati viszonyba léphetnek át, így a katonai pálya vonzóbbá tehető a hiányszakmák terén. Az átmenetet elősegítendő tervezik a minimális korhatár (jelenleg betöltött 24 . életév) lecsökkentését is. ${ }^{46}$

\section{Illetmények, juttatások}

A Bundeswehrben jelenleg a Magyar Honvédséghez hasonlóan az alapilletmény rendfokozattól és fizetési szintektől függ, amelyeket befolyásol az életkor és tapasztalat, ehhez hozzáadódnak a speciális szolgálati pótlékok, mint például a századparancsnoki, tengerészeti, pilóta-, egészségügyi dolgozói pótlékok. E pótlék, míg a századparancsnok esetében havi 100-150 euró, addig a szakorvosok esetében 615 euró, illetve a pilótáknál közel 1244 euró ${ }^{47} \mathrm{~A}$ családi állapottól függően (házastárssal rendelkező, gyermekes, özvegy, elvált) családi pótlék jár. A házas vagy eltartást fizető, gyermekes katonáknak és civil alkalmazottaknak az első fizetési fokozatban havi 149,36 euró, a második fokozatban 277 euró családi pótlék jár. Az összes fizetési csoportban minden gyermek után 127,66 euró, a harmadik gyermektől pedig 398 euró pótlék jár. ${ }^{48} \mathrm{~A}$ juttatásokon és pótlékokon felül érdemes megemlíteni, hogy a hivatásos és szerződéses állomány fizetéséből kevesebb járulékot és adót

\footnotetext{
42 Bundeswehr: Die Laufbahn der Offiziere. [online], Forrás: bundeswehr.de [2020. 12. 07.]; Bundeswehrkarriere: Offizier mit Studium in der Laufbahn der Offiziere. (é. n.) i. m.

43 Deutsche Bundestag: Unterrichtung durch den Wehrbeauftragten. Jahresbericht 2019 (61. Bericht) (2020) i. m. 32.

44 Bundeswehr: Korporal und Stabskorporal - FAQ für Soldaten und Soldatinnen. [online], 2020. 08. 25. Forrás: bundeswehr.de [2020. 12. 07.]; Bundeswehr: Grundlegendes. [online], Forrás: bundeswehr.de [2020. 12. 07.]

45 Deutsche Bundestag: Unterrichtung durch den Wehrbeauftragten. Jahresbericht 2019 (61. Bericht) (2020) i. m. 33.

46 Bundeswehr: Als Fachunteroffizier Berufssoldatin oder Berufssoldat werden. [online], 2019. 11. 25. Forrás: bundeswehr. de [2020. 12. 07.]

47 Bundeswehr: Die Zulagen für Soldatinnen und Soldaten. [online], 2019. 11. 25. Forrás: bundeswehr.de [2020. 12. 07.]

48 Bundeswehr: Besoldungstabellen: Grundgehälter von Soldaten und Beamten. [online], Forrás: bundeswehr.de [2020. 12.07.]
} 
vonnak le, így például a társadalombiztosítás után nem vonnak le járulékot, továbbá egyes biztosítások (például gépjármübiztosítás) vagy szolgáltatások (például internet) kedvezményesen vehetők igénybe. ${ }^{49}$

A szemléltetés végett néhány példa az átlagos keresetekre: egy önkéntes szolgálati viszonyban lévő lövész 18 évesen, egyedülállóként havi bruttó 1500 euróra számíthat, ugyanígy egy szerződéses lövész 2301 euróra, egy örmester 2617 euróra. ${ }^{50}$ Egy tanulmányait folytató hadapródőrmesteri rendfokozatú tisztvárományos 20 évesen, gyermek nélkül havi bruttó 2390 eurót, tanulmányai után fỏhadnagyként házasan bruttó 3421 eurót, majd századosként 28 évesen két gyermekkel havi bruttó 4348 eurót kap havonta. ${ }^{51}$

Az Agenda Attraktivitätben fontos szerepet kap a versenyképes fizetési struktúra kialakítása. A 2020. január 1. óta hatályban lévő fizetési struktúrák megújításáról szóló törvény (teljes német nevén: Gesetz zur Modernisierung der Strukturen des Besoldungsrechts und zur Änderung weiterer dienstrechtlicher Vorschriften) jelentős javulást hozott a közszolgálati, rendvédelmi és katonai alkalmazottak juttatásaiban. A törvény értelmében többek között megemelt juttatás (havi 91 euró) jár azoknak a katonáknak, akik hosszan tartó megterhelés alatt például tengeri müveletben vagy valamilyen müveleti felkészülésben vesznek részt. Ezenfelül a külföldi kiküldetésért járó pótlékot is megemelték legfeljebb havi 145 euróra, illetve a századőrmesterek pótlékát havi 135 euróra emelték. ${ }^{52}$ A meglévő juttatások mellett új pótlékokat is bevezettek, például vezetői pótlék jár bizonyos vezetői feladatkörökért közel 150 euró értékben, maximum 300 eurós pótlék jár a kibervédelmet ellátók számára, 350 eurós tengeri utazási pótlékot kapnak a felszíni hajón, 700 eurót a tengeralattjárókon szolgálók, vagy legfeljebb 500 eurós pótlék jár a különleges erőknek. ${ }^{53}$

A németországi átlagkeresetet tekintve (havi bruttó 3994 euró) a Bundeswehrben szolgálók átlagkeresete (megközelítőleg havi 4000 euró) átlagosnak mondható, azonban elmarad az informatikai vagy a pénzügyi, de még az oktatási szektor átlagkereseteihez képest is, nem beszélve arról, hogy a civil foglalkozásokkal ellentétben a katonák számos nehezítő tényezővel (külföldi missziók, pszichikai-fizikai terhelés) néznek szembe életpályájuk folyamán. ${ }^{54} \mathrm{~A}$ fizetés tehát önmagában nem teszi vonzó munkaadóvá a Bundeswehrt. Mindezek mellett kétségtelen előnye, hogy stabil munkahelyet kínál, még az esetleges gazdasági válságok, így a koronavírus okozta válsághelyzet közepette is. ${ }^{55}$

49 Bundeswehr und Freizeitshop: Die Vorteile als Soldat: Rabatte und Vergünstigungen. [online], Forrás: bw-online-shop. com [2020. 12. 09.]

50 Bundeswehr: Bezügebeispiele für die Laufbahn der Mannschaften. [online], Forrás: bundeswehr.de [2020. 12. 07.]; Bundeswehr: Bezügebeispiele für die Laufbahn der Feldwebel. [online], Forrás: bundeswehr.de [2020. 12. 07.]

51 Bundeswehr: Bezügebeispiele für die Laufbahn der Offiziere. [online], Forrás: bundeswehr.de [2020. 12. 07.]

52 Öffentlicher Dienst News: Soldatenbesoldung 2020: Was Offiziere, Unteroffiziere und Soldaten bei der Bundeswehr verdienen. [online], 2020. 03. 01. Forrás: oeffentlicher-dienst-news.de [2020. 12. 07.]

53 Deutsche Bundestag: Unterrichtung durch den Wehrbeauftragten. Jahresbericht 2019 (61. Bericht) (2020) i. m. 61-62.

54 Statista: Durchschnittsgehalt in Deutschland. [online], 2020. 12. 04. Forrás: de.statista.com [2020. 12. 07.]; Statista: Durchschnittliche Bruttomonatsverdienste vollzeitbeschäftigter Arbeitnehmer (ohne Sonderzahlungen) nach Wirtschaftsbereichen im 2. Quartal 2020. [online], Forrás: de.statista.com [2020. 12. 07.]

55 Bundeswehr: Bundeswehr wächst - Personalbilanz auch bei Fachkräften gut. [online], 2020. 07. 17. Forrás: bundeswehr. de [2020. 12. 11.] 


\section{Egyéb vonzerönövelő intézkedések}

Az Agenda Attraktivität a juttatások emelésén felül a család és a hivatás összeegyeztetésével is igyekszik növelni a katonai hivatás vonzerejét. Lévén, hogy a katonai hivatás hosszú ingázási idővel jár az otthon és a munkahely között, ezért a Bundeswehr egyre inkább nyitott a távmunkavégzés irányában. Az ingázás elkerülése végett a Bundeswehr a kötelező sporttevékenység helyszíneit is igyekszik közelebb vinni az alkalmazottak otthonaihoz. A részmunkaidőt ezzel szemben csak alapos indokkal engedélyezik, elsősorban csak a szülői szabadság alatt. Az elmúlt években a Bundeswehr pilotprojektként bevezette a családszolgáltatást (Familienservice), amely az awo life balance Gmbh szolgáltatóvállalaton keresztül szükséghelyzetekben 24 órán belül gyermekgondozást vállal, költségeit a védelmi minisztérium fizeti. ${ }^{56} \mathrm{~A}$ fenti családtámogató intézkedések azért is fontosak, mivel a védelmi minisztérium növelni kívánja a nők arányát a haderőben. A megvalósítás eredményesnek mutatkozik, mivel 2015-2018 között 10,5\%-ról 12,1\%-ra nőtt a nők aránya. ${ }^{57}$

A számos vonzerőt növelö intézkedés közül kiemelendő még, hogy a védelmi minisztérium számos laktanyát, katonai infrastruktúra-létesítményt modernizál, illetve újít fel. Egy 2015-ös miniszteri jelentés szerint a katonai szálláshelyek és szolgálati épületek alig fele volt „jó vagy közepes” állapotban. A helyzetet orvosolandó a védelmi minisztérium a katonai infrastruktúrára szánt összeget 2015-2018 között közel 240 millió euróval növelte meg. ${ }^{58}$

\section{Nyugdijazás}

A katonák jogállásáról szóló törvény (Gesetz über die Rechtstellung der Soldaten, röviden Soldatengesetz) szabályozza a katonák nyugdíjkorhatárát, amely rendfokozattól, beosztástól és szolgálati viszonytól függ. Így például a tábornoki, ezredesi rendfokozatúak, valamint a tiszti életpályán lévő egészségügyi, katonaizenész- és geoinformációs szolgálatot ellátók 65. életévükben mehetnek nyugdíjba, minden más hivatásos katona pedig 62 . életévében. ${ }^{59}$ A törvény azonban a hivatásosok számára rendfokozattól függően úgynevezett különleges nyugdíjkorhatárt is megállapít (például 55. életév a tiszthelyettes, 61. év a föhadnagy esetében), ami a személyzeti struktúra rugalmasabb alakítását teszi lehetővé. ${ }^{60} \mathrm{~A}$ haderő létszámcsökkentése idején, 2015-ig szokássá vált, hogy a Bundeswehr a különleges nyugdíjkorhatár elérésével automatikusan nyugdíjazta a hivatásos katonákat. ${ }^{61} \mathrm{~A}$ honvédelmi megbízott azonban felhívja arra a figyelmet, hogy a Személyzeti Irányváltás programjával

\footnotetext{
56 Deutsche Bundestag: Unterrichtung durch den Wehrbeauftragten. Jahresbericht 2019 (61. Bericht) (2020) i. m. 85-86.

57 Bundesministerium der Verteidigung: Gleichstellung: Bundeswehr fördert Frauen. [online], 2020. 01. 15. Forrás: bmvg. de [2020. 12. 15.]

58 Deutsche Bundestag: Unterrichtung durch den Wehrbeauftragten. Jahresbericht 2018 (60. Bericht). [online], 2019. 01. 29. 49. Forrás: dip21.bundestag.de [2020. 12. 15.]

59 Buzer: Gesetz über die Rechtsstellung der Soldaten (Soldatengesetz - SG). [online], 44. \$ (1)-(2) bekezdés. Forrás: buzer. de [2020. 12.07.]

${ }^{60}$ Buzer: Gesetz über die Rechtsstellung der Soldaten (Soldatengesetz - SG). [online], 44. $\$(1)$ bekezdés. Forrás: buzer.de [2020. 12.07.]

${ }_{61}$ Deutscher BundeswehrVerband: Zurruhesetzung: Zusicherungserlass bietet Chance auf mehr Mitbestimmung. [online], 2020. 06. 23. Forrás: dbwv.de [2020. 12. 07.]
} 
összhangban, vagyis a létszám minél gyorsabb növelése érdekében szükséges lehet visszatérni a törvényben meghatározott általános nyugdíjkorhatárokhoz. ${ }^{62}$

\section{Tartalékosok és önkéntes szolgálatot teljesitők}

Ahogy a Humán Stratégia kapcsán említettük, a személyzeti reform célja a tartalékosi szolgálat népszerüsítése is. Jelenleg közel 29 ezer tartalékos teljesít szolgálatot a Bundeswehrben. ${ }^{63}$ 2019 októberében új Tartalékos Stratégiát (Strategie der Reserve) adott ki a védelmi minisztérium, a Bundeswehr 2032-ig szóló képességprofiljával összhangban. ${ }^{64}$ A stratégia egyik legfontosabb rendelkezése, hogy minden megfelelő képesítéssel rendelkező katonát aktív szolgálatának befejezésével valamelyik tartalékosi szolgálati pozícióba sorolnak, amelyet válsághelyzet esetén be kell tölteniük. A tartalékosi gyakorlatokon való részvétel egyelőre önkéntes alapon müködik. ${ }^{65}$

A védelmi minisztérium és a Bundeswehr számos intézkedéssel igyekezett népszerüsíteni a tartalékos szolgálatot. Ilyen intézkedés például, hogy 2020-tól a tartalékosok ugyanazon juttatásokat kapják, mint a szerződésesek és a hivatásosok. A rövid szolgálati időt teljesítő tartalékosok automatikusan kapnak pótlékot a tizenötödik szolgálati napjuktól a huszonötödikig. A tartalékos szolgálatot továbbá lehetővé tették részmunkaidős foglalkozásban is. További ösztönző elem, hogy a munkáltatók egyszeri juttatást kapnak, ha alkalmazottjuk tartalékos szolgálatra bevonul, és pótolniuk kell emiatt az üresedést. ${ }^{66}$

Az önkéntes szolgálat évek óta nem mondható népszerünek. Míg a sorkötelesség felfüggesztése után 2012-ben 19300 fő jelentkezett, addig 2018-ban már csak 10700 fö, 2019-ben kisebb növekedést elérve, 11200 fö. A védelmi minisztérium szerint a csökkenés oka, hogy 2016 után a létszámnövekedést elsősorban a szerződéses állomány növelésével kívánják elérni, mivel a szerződéses szolgálat legalább 24 hónapra szól. A jelenlegi védelempolitikai vezetés azonban 2020 szeptemberétől új programot hirdetett meg „Önkéntes szolgálat a honvédelemben" (Freiwillige Wehrdienst im Heimatschutz) címmel, amelynek keretében évi 1000 fiatalt kívánnak toborozni a belföldi katasztrófa- vagy válsághelyzetek (például a koronavírus-járvány) kezelésére. A program egy héthónapos önkéntes szolgálati és egy öthónapos tartalékosi szolgálatból áll és havi 1550 eurós illetménnyel jár. Az önkéntes szolgálatot teljesítők szerződéses vagy hivatásos életpályára léphetnek. ${ }^{67} \mathrm{~A}$ honvédelmi megbízott szerint a legfőbb probléma az önkéntes szolgálattal, hogy sokan a próbaidő alatt visszamondják magánéleti, egészségügyi okokból, vagy csak átmeneti elfoglaltságként tekintenek rá, de nem ritka az sem, hogy az elöljárók bánásmódja miatt lépnek ki. ${ }^{68}$

62 Deutsche Bundestag: Unterrichtung durch den Wehrbeauftragten. Jahresbericht 2019 (61. Bericht) (2020) i. m. 38.

63 Gerd Portugall: Wie viel Reservisten hat die Bundeswehr?. [online], 2020. 05. 15. Forrás: behoerden-spiegel.de [2020. 12.09.]

64 Bundeswehr: Ministerin hat neue Strategie der Reserve in Kraft gesetzt. [online], 2019. 11. 25. Forrás: bundeswehr.de [2020. 12. 09.]

65 Deutsche Bundestag: Unterrichtung durch den Wehrbeauftragten. Jahresbericht 2019 (61. Bericht) (2020) i. m. 41.

66 Deutsche Bundestag: Unterrichtung durch den Wehrbeauftragten. Jahresbericht 2019 (61. Bericht) (2020) i. m. 41-42.

67 Deutscher BundeswehrVerband: Bewerbezahl für den freiwilligen Wehrdienst weiter niedrig. [online], 2020. 08. 03. Forrás: dbwv.de [2020. 12. 09.]; Birgit Schmeitzner: Freiwillige für Heimatschutz gesucht. [online], 2020. 09. 01. Forrás: tagesschau.de [2020. 12.11.]

68 Deutsche Bundestag: Unterrichtung durch den Wehrbeauftragten. Jahresbericht 2019 (61. Bericht) (2020) i. m. 40. 
A koronavírus-járvány kapcsán Németországban újra felmerült a sorkötelesség visszaállítása. A védelmi minisztérium szerint a járvány rámutatott arra, hogy a Bundeswehr fontos szerepet tud betölteni a belföldi válsághelyzetek kezelésében is, ezért is indítja a fent említett új önkéntes szolgálati programot. Az új honvédelmi megbízott Eva Högl azonban ennél is messzebbre ment, mivel a sorkötelesség visszaállítását javasolta. A javaslatot Annegret Kramp-Karrenbauer védelmi miniszter, a Zöldek és a Die Linke párt is ellenzi. ${ }^{69}$

\section{Humánerőforrás-hiányok}

A Szövetségi Védelmi Minisztérium a haderő növekvő létszámát a személyzeti reform sikereként könyveli el, különösen az erős munkaerőpiaci konkurencia és a demográfiai változások tükrében, azonban a Bundestag honvédelmi megbízottjának 2019. évi jelentése árnyalja e képet. A 2016-os személyzeti reform után a Bundeswehrbe jelentkezők száma továbbra is csökkent, majd elöször 2019-ben ismét növekedni kezdett. 2019-ben összesen 20172 katonával bővült a haderö, ami azonban csekély növekedés az előző évi 20012 főhöz képest. A jelentés kihangsúlyozza, hogy a jelenlegi számok mellett a csapatszolgálatban a legénységi és az őrmesteri létszámcélok nem érhetők el, a toborzás nehézkes a légi, az egészségügyi, az elektronikai, valamint szinte minden technikai szaktudást igénylö területen. ${ }^{70}$

A jelentés szerint a korábbi évekhez hasonlóan 2019-ben továbbra is több mint 20 ezer betöltetlen tiszti és tiszthelyettesi státusz volt, míg a legénységi állományban 2100 . Komoly személyhiány jelentkezik a szárazföldi haderőnemen (Heer) belül a távközlés terén: míg az alacsonyabb rendfokozatú tiszthelyettesi állományban csak minden második státusz van betöltve, addig a magasabb tiszthelyettesi rendfokozatúaknál csak 64\%-os, a tiszti állományban pedig 75\%-os a feltöltöttség. Ugyanígy jelentős hiányosság van a felderítő tiszti (70\%-os feltöltöttség), illetve a repüléstechnikai tiszti (53\%-os feltöltöttség) állományban, továbbá a tüzér fegyvernem legénységi, tiszthelyettesi és tiszti állománycsoportjaiban. A haditengerészetben a pszichikai és fizikai terhelés miatt évek óta súlyos személyzethiány van: minden második tiszti státusz betöltetlen, de e haderőnemnél is elsősorban a technikai szaktudást igénylő tiszthelyettesi státuszok betöltetlenek, így például az elektronikai felderítésben minden második státusz nincs betöltve. A légierőben az utóbbi években új státuszok jöttek létre, amelyeket szintén fel kellene tölteni személyzettel. Bár a védelmi minisztérium tett lépéseket például a pilótaszolgálat népszerüsítése érdekében, azonban a honvédelmi megbízott szerint ennek kevés eredménye látható. İgy például a légi szállítás terén a tiszti állomány feltöltöttsége $67 \%$-os, a pilóta nélküli repülőeszközök személyzetében pedig csak 36\%-os (!). Ez utóbbi arány különösen elgondolkodtató, tekintve, hogy napjainkban a pilóta nélküli repülőeszközök fontos szerepet kapnak a modern hadviselésben. Az Eurofighter vadászgépeknél évek óta személyzethiány van a pilótaképzésben, amelyet a védelmi minisztérium ideiglenes megoldásként 2022-ig a képzések külföldre való kiszervezésével próbál orvosolni. A helikopterpilóta-státuszok betöltöttsége 74\%-os, a hiány különösen a szállítóhelikopter-személyzetben mutatkozik meg. A védelmi minisztérium a légierő személyzethiányának orvoslása érdekében 2019-ben munkacsoportot

${ }_{69}$ Tagesschau: Freiwilligendienst oder Wehrpflicht?. [online], 2020. 07. 14. Forrás: tagesschau.de [2020. 12. 11.]

70 Deutsche Bundestag: Unterrichtung durch den Wehrbeauftragten. Jahresbericht 2019 (61. Bericht) (2020) i. m. 20-21. 
hozott létre, amely a toborzást többek között az ellenőrzési kapacitás növelésével és a szolgálatba való visszatérés lehetőségeinek bővítésével kívánja erősíteni, továbbá a hivatásos katonák számára megnyílt a lehetőség, hogy katonai szakszolgálati pozíciót tölthessenek be. A védelmi minisztérium igencsak optimista álláspontja szerint a hiányosságok nem veszélyeztetik a Bundeswehr készenlétét. ${ }^{71}$

A Bundeswehr Központi Egészségügyi Szolgálatában a fötisztisebész-státuszok háromnegyede van betöltve. A szakorvoshiányt a védelmi minisztérium fizetésemeléssel korrigálta, így a státuszok növekedése ellenére némiképp sikerült növelni a feltöltöttséget. Ezzel párhuzamosan azonban a támogató egészségügyi személyzetben továbbra is hiány van. A honvédelmi megbízott szerint az egészségügyi munkaerőhiány miatt a müveleti készenlét csak korlátozott ideig tartható fenn az alapszintü müveletek esetében is. A 2017-ben létrehozott Kiber- és Információs Tér szervezeti elem állományához szintén nehézségekbe ütközik a toborzás (a státuszok negyede betöltetlen), mivel nem egy esetben magasan képzett személyzetre van szükség. A státuszok feltöltése csak évekkel később lesz lehetséges, mivel a kiképzés időt vesz igénybe, mialatt nem kevesen fel is mondanak. Az információtechnológia állományának növelése érdekében a védelmi minisztérium különböző célzott hirdetőkampányokat, karrier-tanácsadásokat folytat a munkaerőpiac felé, valamint a meglévő IT-szakállomány számára biztosít továbbképzést. A civil szakemberek bevonzása nem bizonyul sikeresnek, mivel a kiberállománynak csak mindössze $13 \%$-a civil alkalmazott. ${ }^{72}$

A honvédelmi megbízott jelentése rávilágít arra, hogy a munkaerőhiány azonban nemcsak a toborzási nehézségekre, hanem a szervezeti problémákra is visszavezethetö. 2019-ben a 183667 főből 43100 fő szolgálathoz hasonló posztot töltött be, így például képzéseken (például civil foglalkozású vagy felsőoktatási) vettek részt. ${ }^{73}$

Aggasztó tendencia, hogy növekszik azok száma, akik a szolgálatot az első félévben mondják vissza, vagy akiket a Bundeswehr elbocsát: 2019-ben 4260 fö, ebböl 3833 saját döntéséből távozott. A minisztérium eddig nem tárta fel a távozók motivációját, értékelése szerint e számok nem különböznek a munkaerőpiacétól. ${ }^{74}$

A csekély állománynövekedés a honvédelmi megbízott szerint annak köszönhető, hogy a hivatásosok és a szerződésesek tovább maradnak szolgálatban, nem utolsósorban a 2016-ban foganatosított ösztönző intézkedések miatt. Ezenfelül növekszik az idősebb korosztályú újonnan belépők és újra belépők, illetve a tartalékosok száma, ami egyúttal az állomány átlagéletkorának növekedését eredményezi. Az állomány átlagéletkora 2012-ben a sorkötelezettség felfüggesztésével 30,3 év, majd 2019-ben 32,3 év lett, a tisztek átlagéletkora 2012 és 2019 között közel egy évvel nőtt. Nemzetközi összehasonlításban ez átlagosnak mondható, az Egyesült Királyságban például ugyanígy 32, Franciaországban 33, Belgiumban pedig 44 év. ${ }^{75} \mathrm{Az}$ átlagéletkor növekedése nem meglepő fejlemény, mivel a német társadalom öregedésével párhuzamosan a haderő átlagéletkora is növekszik, e ten-

\footnotetext{
Deutsche Bundestag: Unterrichtung durch den Wehrbeauftragten. Jahresbericht 2019 (61. Bericht) (2020) i. m. $23-25$.

Deutsche Bundestag: Unterrichtung durch den Wehrbeauftragten. Jahresbericht 2019 (61. Bericht) (2020) i. m. $25-26$.

Deutsche Bundestag: Unterrichtung durch den Wehrbeauftragten. Jahresbericht 2019 (61. Bericht) (2020) i. m. 26.

Deutsche Bundestag: Unterrichtung durch den Wehrbeauftragten. Jahresbericht 2019 (61. Bericht) (2020) i. m. 20-21.

75 Deutsche Bundestag: Unterrichtung durch den Wehrbeauftragten. Jahresbericht 2019 (61. Bericht) (2020) i. m. 22.
} 
denciához igazodva a Humán Stratégia célul tüzte ki, hogy a Bundeswehr a 30 éven felüli korosztályt is be tudja vonzani. ${ }^{76}$

Végül a munkaerőhiány pótlását a koronavírus-járvány is nehezíti. 2020 első öt hónapjában 14\%-kal kevesebben jelentkeztek, mint 2019 ugyanezen időszakában. A járványhelyzet magát a toborzási folyamatot is hátrányosan érinti, így a lezárások alatt közel 10 ezer kiértékelés elmaradt. ${ }^{77}$

\section{Összefoglalás és értékelés}

A Bundeswehr személyzeti reformja a müncheni konszenzus által kialakított új német védelempolitikai irány jelentős eredményének tekinthetö. Az új Humán Stratégia megalkotása önmagában bizonyítja, hogy a német védelempolitikában megmutatkozott a szándék a Bundeswehr európai szinten (ismét) meghatározó haderővé történő fejlesztésére, egyúttal a haderő képességeinek növelésére az új német és szövetségi biztonságpolitikai prioritások tükrében. A német védelempolitika elkötelezettségét az is jelzi, hogy az új stratégiai dokumentumban foglalt számos kezdeményezés és program végrehajtása, valamint azok jogi feltételeinek megteremtése már megtörtént vagy folyamatban van, valamint hogy a politikai vezetés a haderő fenntartható fejlesztése érdekében stratégiai tervezési eljárást vezetett be a mindenkori elérendő létszám meghatározásában. A személyzeti reform tehát arra enged következtetni, hogy a német védelempolitikában napjainkban tapinthatóbbá válik egyfajta stratégiai gondolkodás.

A Humán Stratégia céljának megvalósítása érdekében (vagyis hogy a Bundeswehr versenyképes munkaadó legyen, és megfelelő személyzettel rendelkezzen) az elmúlt négy évben valós, konkrét intézkedések történtek, amelyek mind hozzájárulhattak ahhoz, hogy a haderő létszáma a korábbi évekkel ellentétben stabilizálódni látszik és enyhe növekedésnek indul. Így kiemelendő, hogy a Bundeswehr a társadalom számára pozitív képet sugároz azzal, hogy nem pusztán egy fegyveres erőként, hanem stabil, megbízható, életre szóló hivatást és fejlődési, tanulási lehetőségeket kínáló munkaadóként tünteti fel magát. Ennek megnyilvánulása, hogy oktatási, képzési szervezetként Németország egyik legszélesebb körű képzésprofiljával rendelkezik, amely révén képes megszólítani a katonai hivatás iránt érdeklődőket, és egyben perspektívát is kínál a katonai szolgálaton túli civil életre. Kiemelendő továbbá, hogy a Bundeswehr megemelte az illetményeket, pótlékokat, valamint egyre több kezdeményezése (például családtámogatás, laktanya-felújítások) igyekszik javítani a katonák életkörülményein. A katonai életpályák rugalmasabbá tétele szintén vonzóbbá teheti a Bundeswehrt.

A Bundeswehr Hadtörténeti és Társadalomtudományi Központjának (Zentrum für Militärgeschichte und Sozialwissenschaften der Bundeswehr) 2020-as felmérése bizonyítja, hogy az alkalmazottak szempontjából a személyzeti reformintézkedések sikeresnek bizonyultak: míg 2013-ban a Bundeswehr alkalmazottjainak csak 39\%-a vélte vonzó munkaadónak a haderőt, addig 2016-ban 59\%, 2020-ban pedig már 68\%. Továbbá 2013-ban

\footnotetext{
76 Deutsche Bundestag: Unterrichtung durch den Wehrbeauftragten. Jahresbericht 2017 (59. Bericht). [online], 2018. 02. 20. 20. Forrás: dip21.bundestag.de [2020. 12. 01.]

77 Bundeswehr: Corona-Krise: Bundeswehr bleibt attraktiver Arbeitgeber und will weiter wachsen (2020) i. m.
} 
az alkalmazottak 23\%-a javasolta volna a Bundeswehrt mint munkaadót, 2020-ban pedig már 42\%, 2013-ban az alkalmazottak 23\%-a volt elégedett a szolgálattal, 2020-ban már 34\%. Árulkodó eredményei a felmérésnek, hogy a Bundeswehr alkalmazottai elsősorban a munkahelyi biztonságot, a szociális munkaközeget és a munkatevékenység érdekességét emelték ki a Bundeswehr mint munkaadó pozitívumaként. A felmérés alapján szintén az Agenda Attraktitvität eredményének tekinthető, hogy a Bundeswehr a legtöbbet a család és szolgálat egyensúlya, a karriertámogatás, a gyermekgondozás, valamint fejlődési és továbbképzési lehetőségek terén fejlődött. ${ }^{78}$ Ugyanakkor a központ felmérése szerint 2015-2019 között a haderő munkaadói vonzereje a német társadalom szemében alig változott: a válaszadók 62-68\%-a tartotta vonzó munkaadónak. A reformok tehát csak kis mértékben voltak hatással a haderő társadalommal szembeni vonzerejére. ${ }^{79}$

A pozitív eredmények ellenére mégis látható, hogy a személyzeti reform nem képes (legalábbis egyelöre) kezelni a Bundeswehr „akut” problémáit. Bár pozitívnak mondható, hogy az intézkedések a munkaerőhiányt elsősorban a meglévő állomány hatékonyabb kiaknázásával kívánják orvosolni (tartalékosi szolgálat kiterjesztése, életpályák rugalmasabbá tétele, juttatások emelése), a fiatal korosztályt megszólító újonctoborzási intézkedések (hirdetőkampányok, állásbörzék, YouTube-sorozatok) figyelemfelhívóak, azonban kevésbé tudják bent tartani a jelentkezőket, mivel gyakran nem reális képet közvetítenek a katonai szolgálatról, így például nem kerül előtérbe a hosszú, családtól távol végzett szolgálat (haditengerészetnél) vagy a külföldi missziók nehézségei. Átképzésekkel, életpálya-módosításokkal márpedig nem oldható meg hosszú távon a több éves szakmai felkészítést igénylő pozíciókat (például orvos, pilóta, technikus, informatikus) érintő szakemberhiány. Emellett a meglévő állomány kiaknázása gyakoribb munkahelyi kiégéshez, motivációvesztéshez is vezethet. Nem elhanyagolható a tény, hogy a szakemberhiány pont a modern hadviselés szempontjából elengedhetetlen területeken (pilóta nélküli repülőgépek, légierö, kibervédelem, elektrotechnika) jelentkezik, ami komolyan fenyegeti a Bundeswehr müveleti képességeit.

A koronavírus-járvány alatt megnövekedett terhelés rámutat a Bundeswehr „gyenge pontjára”, vagyis hogy a meglévő külföldi missziók mellett nehezen tud egy további nagyszabású műveletet közép- és hosszú távon végezni, nem beszélve arról, ha európai vezető nemzetként egy magas intenzitású konfliktusban kellene részt vennie. Bár jelenleg úgy tünik, hogy a Bundeswehr személyzeti reformja lassan, de jó úton halad a létszám és a vonzerö növelése felé, kétséges, hogy mennyire lesz ez elég arra, hogy a 21. század gyorsan változó biztonsági környezetében eleget tegyen a német védelempolitika ambícióinak. ${ }^{80}$

78 Gregor Richter: Wie attraktiv ist die Bundeswehr als Arbeitgeber? Ergebnisse der Personalbefragung 2020. [online], 2020. 11. 25. 34. Forrás: Zentrum für Militärgeschichte und Sozialwissenschaften der Bundeswehr [2020. 12. 14.]

79 Markus Steinbecher - Timo Graf - Heiko Biehl: Sicherheits- und verteidigungspolitisches Meinungsbild in der Bundesrepublik Deutschland Ergebnisse und Analysen der Bevölkerungsbefragung 2019. [online], Zentrum für Militärgeschichte und Sozialwissenschaften der Bundeswehr, 2019. 12. 127-128. Forrás: opus4.kbv.de [2020. 12. 14.]

80 Így például a szövetségi kormány 2020 novemberi indopacifikus térségre vonatkozó stratégiájában szerepel, hogy a Bundeswehr haditengerészeti jelenlétét fokozni kell a térség biztonság érdekében. Lásd: Jerry Sommer: Der IndoPazifik - bald Operationsgebiet der Bundeswehr?. [online], 2020. 11. 12. Forrás: ndr.de [2020. 12. 16.] 


\section{FELHASZNÁLT IRODALOM}

Augen geradeaus: Personalstärke im August 2020: Mühsamer Aufstieg, jetzt wieder knapp über 184.000. [online], 2020. 09. 28. Forrás: augengeradeaus.net [2011. 11. 10.]

Bundesministerium der Verteidigung: Gleichstellung: Bundeswehr fördert Frauen. [online], 2020. 01. 15. Forrás: bmvg.de [2020. 12. 15.]

Bundesministerium der Verteidigung: Personalbedarf bis 2027: Bundeswehr braucht mehr Zivilpersonal. [online], 2020. 05. 08. Forrás: bmvg.de [2020. 12. 01.]

Bundesministerium der Verteidigung: Weißbuch 2016 zur Sicherheitspolitik und zur Zukunft der Bundeswehr. [online], 2016. 06. Forrás: bmvg.de [2020. 12. 12.]

Bundesministerium für Verteidigung Presse- und Informationsstab Forrás: bmvg.de [2020. 12. 10.] Bundeswehr: Aktuelle Einsätze der Bundeswehr. [online], Forrás: bundeswehr.de [2011. 11. 11.]

Bundeswehr: Als Fachunteroffizier Berufssoldatin oder Berufssoldat werden. [online], 2019. 11. 25. Forrás: bundeswehr.de [2020. 12.07.]

Bundeswehr: Arbeitgeber Bundeswehr im Visier. [online], Ausgabe 01, Frühjahr 2016 Forrás: bundeswehrkarriere. de [2020. 12. 14.]

Bundeswehr: Arbeitgeber Bundeswehr im Visier. [online], Ausgabe 13, Frühjahr 2020,

ZDF: Armee am Limit - Was wird aus der Bundeswehr?. [online], Forrás: zdf.de [2020. 11. 11.]

Bundeswehr: Besoldungstabellen: Grundgehälter von Soldaten und Beamten. [online], Forrás: bundeswehr.de [2020. 12.07.]

Bundeswehr: Bezügebeispiele für die Laufbahn der Feldwebel. [online], Forrás: bundeswehr.de [2020. 12. 07.]

Bundeswehr: Bezügebeispiele für die Laufbahn der Mannschaften. [online], Forrás: bundeswehr.de [2020. 12. 07.]

Bundeswehr: Bezügebeispiele für die Laufbahn der Offiziere. [online], Forrás: bundeswehr.de [2020. 12. 07.]

Bundeswehr: Bundeswehr wächst - Personalbilanz auch bei Fachkräften gut. [online], 2020. 07. 17. Forrás: bundeswehr.de [2020. 12. 11.]

Bundeswehr: Corona-Krise: Bundeswehr bleibt attraktiver Arbeitgeber und will weiter wachsen. [online], 2020. 06. 15. Forrás: bundeswehr.de [2020. 12. 02.]

Bundeswehr: Die Laufbahn der Offiziere. [online], Forrás: bundeswehr.de [2020. 12. 07.]

Bundeswehr: Die Laufbahn der Unteroffiziere mit Portepee (M/W/D). Forrás: bundeswehr.de [2020. 12. 07.]

Bundeswehr: Die Trendwende Personal ist Erfolgreich!. [online], 2019. 11. 29. Forrás: bundeswehr.de [2020. 12. 01.]

Bundeswehr: Die Unteroffiziere ohne Portepee (M/W/D). [online], Forrás: bundeswehr.de [2020. 12. 07.]

Bundeswehr: Die Zulagen für Soldatinnen und Soldaten. [online], 2019. 11. 25. Forrás: bundeswehr.de [2020. 12. 07.]

Bundeswehr: Freiwilliger Wehrdienst (M/W/D): Chance statt Pflicht. [online], Forrás: bundeswehr.de [2020. 12. 02.]

Bundeswehr: Grundlegendes. [online], Forrás: bundeswehr.de [2020. 12. 07.]

Bundeswehr: Korporal und Stabskorporal - FAQ für Soldaten und Soldatinnen. [online], 2020. 08. 25. Forrás: bundeswehr.de [2020. 12.07.]

Bundeswehr: Laufbahn der Mannschaften - Das Rückgrat der Bundeswehr. [online] Forrás: bundeswehr.de [2020. 12.07.]

Bundeswehr: Ministerin hat neue Strategie der Reserve in Kraft gesetzt. [online], 2019. 11. 25. Forrás: bundeswehr. de [2020. 12. 09.]

Bundeswehr: Personalzahlen der Bundeswehr. [online], 2020. 10. Forrás: bundeswehr.de [2020. 12. 02.]

Bundeswehr: Was macht ein Karriercenter?. [online], Forrás: bundeswehr.de [2020. 12. 04.]

Bundeswehrkarriere: Offizier mit Studium in der Laufbahn der Offiziere. [online], Forrás: bundeswehrkarriere. de [2020. 12. 10.]

Bundeswehr und Freizeitshop: Die Vorteile als Soldat: Rabatte und Vergünstigungen. [online], Forrás: bw-onlineshop.com [2020. 12. 09.]

Buzer: Gesetz über die Rechtsstellung der Soldaten (Soldatengesetz - SG). [online], Forrás: buzer.de [2020. 12. 07.]

Csiki Varga Tamás - Etl Alex: Németország stratégiai jövőképe és a Bundeswehr reformfolyamata. [online], Honvédségi Szemle, (2020), 1. 20-32. Forrás: real.mtak.hu [2020. 11. 10.] DOI: https://doi.org/10.35926/HSZ.2020.1.2

Deutsche Bundestag: Unterrichtung durch den Wehrbeauftragten. Jahresbericht 2017 (59. Bericht). [online], 2018. 02. 20. Forrás: dip21.bundestag.de [2020. 12. 01.] 
Deutsche Bundestag: Unterrichtung durch den Wehrbeauftragten. Jahresbericht 2018 (60. Bericht). [online], 2019. 01. 29. Forrás: dip21.bundestag.de [2020. 12. 15.]

Deutsche Bundestag: Unterrichtung durch den Wehrbeauftragten. Jahresbericht 2019 (61. Bericht). [online], 2020. 01. 28. Forrás: [2020. 11. 11.]

Deutscher BundeswehrVerband: Bewerbezahl für den freiwilligen Wehrdienst weiter niedrig. [online], 2020. 08. 03. Forrás: dbwv.de [2020. 12. 09.]

Deutscher BundeswehrVerband: Zurruhesetzung: Zusicherungserlass bietet Chance auf mehr Mitbestimmung. [online], 2020. 06. 23. Forrás: dbwv.de [2020. 12. 07.]

Etl Alex - Csiki Varga Tamás: A Bundeswehr finanszírozása és készenléte. [online], Stratégiai Védelmi Kutatóintézet Elemzések, (2019), 20. 1-12.Forrás: svkk.uni-nke.hu [2020. 11. 10.]

Focus Online:Überlastung der Truppe: Bundeswehr droht der Kollaps - Verbandschef warnt. [online], 2020. 07. 10. Forrás: focus.de [2020. 11. 11.]

Karista: Offizier Gehalt. [online], Forrás: karista.de [2020. 12. 10.]

Kramer, Bernd: Wie oft Bundeswehr in Klassenzimmern wirbt. [online], 2020. 08. 21. Forrás: sueddeutsche.de [2020. 12.10.]

Leyen, Ursula von der: Personalstrategie der Bundeswehr. [online], 2016. Forrás: bmvg.de [2020. 11. 12.]

Major, Claudia - Dominic Vogel: Die neuartige Rolle der Bundeswehr im Corona-Krisenmanagement. [online], Stiftung Wissenschaft und Politik - SWP Aktuell, (2020), 51. 1-8. Forrás: swp-berlin.org [2020. 11. 11.] DOI: https://doi.org/10.18449/2020A51

Meiers, Franz-Josef: Bundeswehr am Wendepunkt. Perspektiven deutscher Außen- und Sicherheitspolitik. Springer VS, 2017. DOI: https://doi.org/10.1007/978-3-658-15710-4

Öffentlicher Dienst News: Soldatenbesoldung 2020: Was Offiziere, Unteroffiziere und Soldaten bei der Bundeswehr verdienen. [online], 2020. 03. 01. Forrás: oeffentlicher-dienst-news.de [2020. 12. 07.]

Portugall, Gerd: Wie viel Reservisten hat die Bundeswehr?. [online], 2020. 05. 15. Forrás: behoerden-spiegel.de [2020. 12. 09.]

Richter, Gregor: Wie attraktiv ist die Bundeswehr als Arbeitgeber? Ergebnisse der Personalbefragung 2020. [online], 2020. 11. Forrás: Zentrum für Militärgeschichte und Sozialwissenschaften der Bundeswehr [2020. 12. 14.]

Schmeitzner, Birgit: Freiwillige für Heimatschutz gesucht. [online], 2020. 09. 01. Forrás: tagesschau.de [2020. 12. 11.]

Schulz, René: Streitkräfte europäischer denken. SWP Aktuell, (2019), 48. 1-4. Forrás: swp-berlin.org [2020. 12. 10.] DOI: https://doi.org/10.18449/2019A48

Sommer, Jerry: Der Indo-Pazifik - bald Operationsgebiet der Bundeswehr?. [online], 2020. 11. 12. Forrás: ndr. de [2020. 12. 16.]

Statista: Durchschnittliche Bruttomonatsverdienste vollzeitbeschäftigter Arbeitnehmer (ohne Sonderzahlungen) nach Wirtschaftsbereichen im 2. Quartal 2020. [online], Forrás: de.statista.com [2020. 12. 07.]

Statista: Durchschnittsgehalt in Deutschland. [online], 2020. 12. 04. Forrás: de.statista.com [2020. 12. 07.]

Steinbecher, Markus - Timo Graf - Heiko Biehl: Sicherheits- und verteidigungspolitisches Meinungsbild in der Bundesrepublik Deutschland Ergebnisse und Analysen der Bevölkerungsbefragung 2019. [online], Zentrum für Militärgeschichte und Sozialwissenschaften der Bundeswehr 2019. 12. Forrás: opus4.kbv.de [2020. 12. 14.] Studium Ratgeber: Studium bei der Bundeswehr. [online], Forrás: studium-ratgeber.de [2020. 12. 10.] Tagesschau: Freiwilligendienst oder Wehrpflicht?. [online], 2020. 07. 14. Forrás: tagesschau.de [2020. 12. 11.] Varwick, Johannes: Von Leistungsgrenzen und Trendwenden. Was soll und kann die Bundeswehr?. [online], Aus Politik und Zeitgeschichte, (2020), 16-17. Forrás: bpb.de [2020. 11. 11.] 